\title{
Effect of advanced injection timing on the performance of natural gas in diesel engines
}

\author{
O M I NWAFOR \\ Department of Mechanical Engineering, Federal University of Technology, \\ Owerri, Imo State, Nigeria
}

MS received 6 July 1998; revised 25 October 1999

\begin{abstract}
Concern over the environment and/or the increasing demand for conventional fossil fuel has promoted interest in the development of alternative sources of fuel energy for internal combustion (IC) engines. The effect of advanced injection timing on the performance of natural gas used as primary fuel in dual-fuel combustion has been examined. Satisfactory diesel engine combustion demands self-ignition of the fuel as it is injected near the top dead centre (TDC) into the hot swirling compressed cylinder gas. Longer delays between injection and ignition lead to unacceptable rates of pressure rise (diesel knock) because too much fuel is ready to burn when combustion eventually occurs. Natural gas has been noted to exhibit longer ignition delays and slower burning rates especially at low load levels hence resulting in late combustion in the expansion stroke. Advanced injection timing is expected to compensate for these effects. The engine has standard injection timing of $30^{\circ}$ before TDC (BTDC). The injection was first advanced by $5.5^{\circ}$ given injection timing of $35.5^{\circ}$ BTDC. The engine ran for about 5 minutes at this timing and stopped. The engine failed to start upon subsequent attempts. The injection was then advanced by $3.5^{\circ}$ (i.e. $33.5^{\circ}$ BTDC). The engine ran smoothly on this timing but seemed to incur penalty on fuel consumption especially at high load levels.
\end{abstract}

Keywords. Advanced injection timing; brake specific fuel consumption; brake thermal efficiency; exhaust temperatures; hydrocarbon emissions.

\section{Introduction}

National interest in developing alternative fuels for IC engines continues to be strong due to environmental concerns and/or the given uncertainties involving the future availability of fossil fuel. This interest lies in identifying alternative sources of fuel energy supply. Natural gas and bio-derived liquids and gas have been the main alternative sources of fuel for IC engines. Recent interest has centred on the use of natural gas in a diesel engine. Natural gas is available in great quantities in many parts of the world. It has a high octane value (research octane number - RON 131), thus making it suitable for engines of high compression ratios with possible improvement of both engine power and efficiency. It does 
not cause fuel dilution of engine oil, which is often a major problem with liquid fuels. In the gas-fuelled dual-fuel engine, the primary fuel is mixed outside the cylinder before it is inducted into the cylinder. A mixture of gas and air is compressed during the compression stroke and, before the end of the stroke, a pilot quantity (about 20\%) of diesel fuel is injected to initiate combustion. The combustion processes of the dual-fuel engine lie between that of the spark ignition engine and the compression ignition (CI) engine. Means for utilization of natural gas in spark ignition (SI) engines are well established whilst development efforts are still geared towards its use in CI engines due to related problems. First, natural gas has a high autoignition temperature $\left(704^{\circ} \mathrm{C}\right)$ compared to diesel fuel $\left(245^{\circ} \mathrm{C}\right)$ and therefore requires a means of initiating combustion. In this case, ignition is brought about by the injection of liquid fuel. Second, it has longer ignition delay and slower burning rate giving rise to increased pressure fluctuations. To meet the challenges posed by these problems, the present work sets out to find the effect of advanced injection timing on the performance of gas-fuelled engines. Test runs were also made on pure diesel fuel in order to establish the baseline for the candidate fuel. The engine was also tested under the standard injection timing of the engine ( $30^{\circ} \mathrm{BTDC}-$ before top dead centre) designated 'standard dual'.

\section{Experimental apparatus}

Test runs were made on a Petter model AC1 single cylinder energy cell diesel engine. It is an air-cooled, high speed, indirect injection four-stroke diesel engine. The energy cell consists of major and minor chambers, which open into the main combustion chamber. The cell induces a secondary turbulence, which aids more complete combustion resulting from good mixing. The dynamometer used to load the engine comprised a shunt wound Maurdsley DC generator and load bank. The reaction force and torque were measured by means of a $100 \times 0.5$ Newton-spring scale. Measurement of combustion chamber pressure was obtained by installing a Kistler type 7063A, sensitivity 79 pc/bar, water-cooled piezo-electric pressure transducer into the air cell of the combustion chamber. The cylinder pressure was displayed on a digital oscilloscope (Nicolet 4094) and stored in a diskette for later analysis of maximum rate of cylinder pressure rise. Pressure in the inlet manifold was measured by a normal Utube manometer. Airflow was measured by means of a viscous-flow meter. Thermocouples were installed to monitor gas temperatures at inlet and outlet ducts as well as cylinder wall temperatures. Fuel was fed to the injector pump under gravity and the volumetric flow rate was measured by the use of a $50 \mathrm{cc}$ graduated burette and stopwatch. Gas flow was measured by a variable area flow rotameter. The engine speed was measured by an in-house designed magnetic pick-up sensor coupled to a frequency meter. The speed was also checked with a Jaquet infrared type digital tachometer. The relative humidity and ambient temperature were monitored by a Vaisala type hygrometer. Natural gas-fuel mixture was controlled by the gas control valve with fuelling taking place in the engine inlet manifold. The $\mathrm{HC}$ emissions were measured by a Rotork flame ionisation detector (FID) analyser model 523. The $\mathrm{CO}$ and $\mathrm{CO}_{2}$ emissions were monitored by an Oliver k550 infrared analyser.

\subsection{Natural gas - typical composition}

Typical composition of natural gas is $2.18 \%$ nitrogen, $92.69 \%$ methane, $3.43 \%$ ethane, $0.52 \%$ carbon dioxide, $0.71 \%$ propane, $0.12 \%$ iso-butane, $0.15 \% n$-butane, $0.09 \%$ pentane and $0.11 \%$ hexane. 
Gross calorific value $=38.59 \mathrm{MJ} / \mathrm{m}^{3}$,

Net calorific value $=34.83 \mathrm{MJ} / \mathrm{m}^{3}$,

Gross Wobbe number $=49.80 \mathrm{MJ} / \mathrm{m}^{3}$,

Stoichiometric $A / F$ ratio $=16.65: 1$,

Net calorific value of diesel fuel $=42.70 \mathrm{~kJ} / \mathrm{kg}$,

Relative density of diesel fuel $=0.844$.

\subsection{Engine data}

The following are data about the characteristics of the engine used. Bore $=76.20 \mathrm{~mm}$, stroke $=66.67 \mathrm{~mm}$, engine capacity $=304 \mathrm{ml}$, compression ratio $=17: 1$, fuel injection release pressure $=18.3 \mathrm{MN} / \mathrm{m}^{2}$, standard fuel injection timing $=30^{\circ} \mathrm{BTDC}$, advanced fuel injection timing $=33.5^{\circ} \mathrm{BTDC}$.

\section{Test results}

\subsection{Advanced injection timing}

Each test cycle was conducted at constant brake mean effective pressure (BMEP) so that the engine would then be required to perform the same task. In diesel engines, only about $80 \%$ of the air inducted can effectively be utilized during the combustion process, the remainder having insufficient time to mix with the fuel. This is one of the reasons why diesel engines of a given capacity have lower power output than petrol engines of the same capacity and speed. In addition, maximum power output of the engine demands that the maximum peak cylinder pressure occur between 5 and $20^{\circ}$ of the crank angle after TDC. To meet these demands, the period of fuel injection was advanced by $3.5^{\circ}$ given injection timing of $33.5^{\circ}$ BTDC. Engine performance deteriorated in an attempt to further advance the timing.

\subsection{Brake specific fuel consumption (BSFC)}

Figure 1a compares the plots of BSFC for diesel fuel and dual-fuel operations at the speed of $3000 \mathrm{rev} / \mathrm{min}$. The plots show marginal increase for the advanced injection system over the dual standard timing operation. The pure diesel fuel operation consistently gave the lowest BSFC throughout the load range. Plots at the speed of $2400 \mathrm{rev} / \mathrm{min}$ show similarity between dual standard and dual advanced injection as shown in figure $1 \mathrm{~b}$. These plots show increase over the baseline test results on diesel fuel, and show that at high load levels, there is little difference between operations. At low load and fuel flow, the difference in BSFC between dual-fuel operations and the pure diesel fuel operation is very significant and converges exponentially with increased load. This is thought to be due to improved combustion at high engine load and temperature. Table 1 compares fuel consumption measurements for the two speeds of investigation. The data show that the advanced timing system incurs penalty on fuel consumption for a given operating condition. The governor injects more pilot fuel than when running on standard time units. It is seen that the poor performance of gas engines at low load levels is due to the effect of gas residuals and low cylinder temperature. It is also due perhaps to the reduction in combustion efficiency caused by reduced flame propagation speed and increased compression work resulting from the large amount of air-gas inducted. 

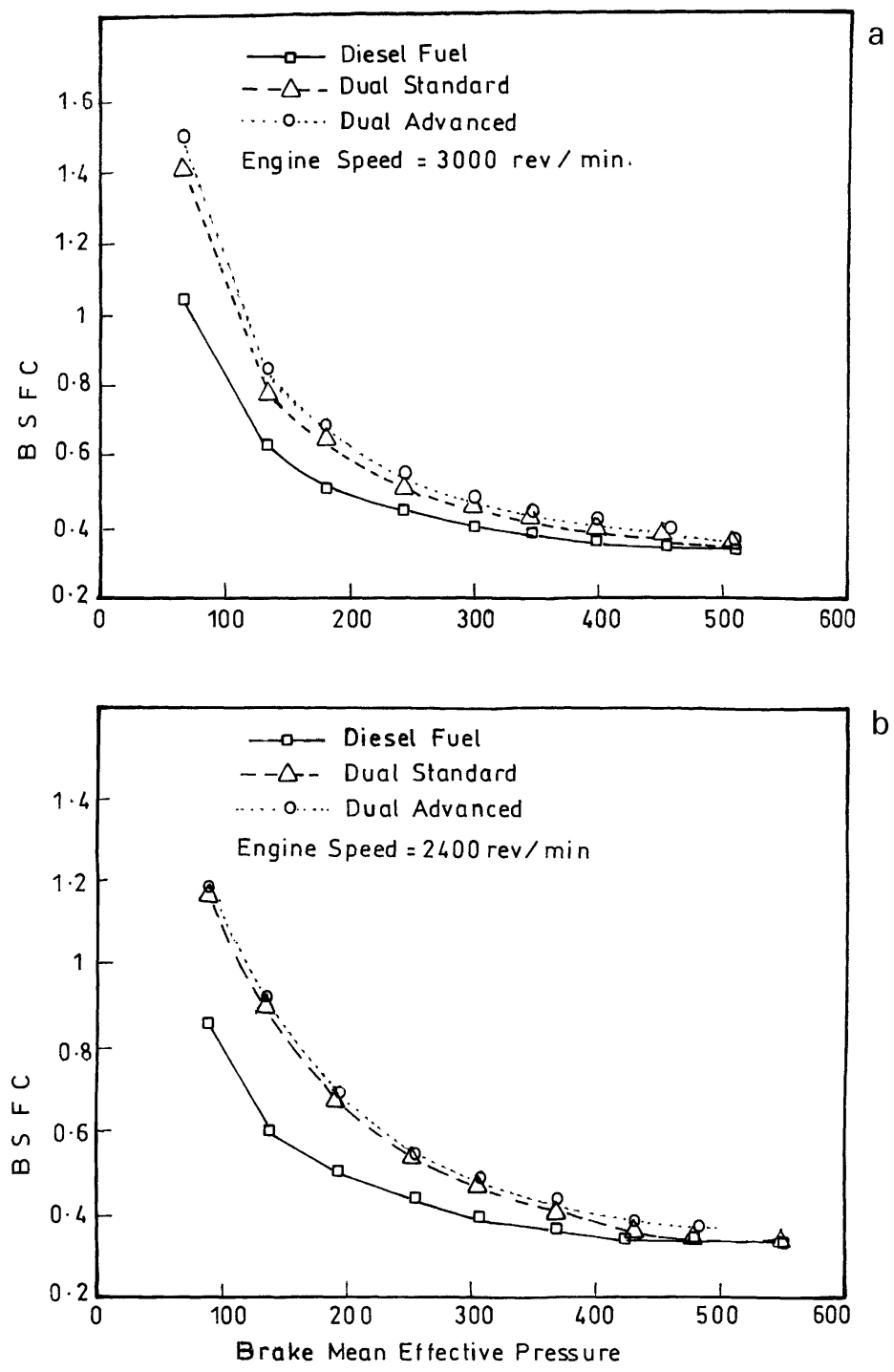

Figure 1. Injection advanced effect on gas combustion - BMEP $\left(\mathrm{kN} / \mathrm{m}^{2}\right)$ vs. BSFC $(\mathrm{kg} / \mathrm{kWh})$.

\subsection{Brake thermal efficiency (BTE)}

Figures $2 \mathrm{a}$ and $\mathrm{b}$ show the trends of BTE plotted against BMEP for speeds of $3000 \mathrm{rev} / \mathrm{min}$ and $2400 \mathrm{rev} / \mathrm{min}$ respectively. The plots showed a very significant difference between dual-fuel operations and runs on pure diesel fuel. Diesel fuel operation produces the highest BTE at the two speeds tested. Standard timing shows little improvement over the advanced system at $3000 \mathrm{rev} / \mathrm{min}$. However, at $2400 \mathrm{rev} / \mathrm{min}$ the dual standard and advanced timing show similar trends at low and intermediate load levels. BTE is defined as the ratio of brake power and the heat supplied. Since the energy density of the gas is low compared to diesel fuel, it is obvious that a greater quantity of natural gas would be required by the engine to 
Table 1. Effect of advanced injection timing on the performance of natural gas.

\begin{tabular}{|c|c|c|c|c|c|}
\hline $\begin{array}{l}\text { Corrected } \\
\text { engine } \\
\text { load }(\mathrm{N})\end{array}$ & $\begin{array}{l}\text { Diesel fuel } \\
\text { operation } \\
(\mathrm{kg} / \mathrm{h})\end{array}$ & $\begin{array}{l}\text { Standard } \\
\text { timing. } \\
\text { Pilot fuel } \\
\text { consumed } \\
(\mathrm{kg} / \mathrm{h})\end{array}$ & $\begin{array}{l}\text { Standard } \\
\text { timing. } \\
\text { Gas } \\
\text { consumed } \\
(1 / \mathrm{min})\end{array}$ & $\begin{array}{l}\text { Advanced } \\
\text { timing. } \\
\text { Pilot fuel } \\
\text { consumed } \\
(\mathrm{kg} / \mathrm{min})\end{array}$ & $\begin{array}{l}\text { Advanced } \\
\text { timing. } \\
\text { Gas } \\
\text { consumed } \\
(1 / \mathrm{min})\end{array}$ \\
\hline \multicolumn{6}{|c|}{ Engine speed $=3000 \mathrm{rev} / \mathrm{min}$} \\
\hline $\begin{array}{l}6.61 \\
13.18 \\
17.72 \\
23.78 \\
29.33 \\
33.87 \\
38.92 \\
44.47 \\
49.52\end{array}$ & $\begin{array}{l}0.539 \\
0.642 \\
0.696 \\
0.818 \\
0.894 \\
0.975 \\
1.045 \\
1.154 \\
1.266\end{array}$ & $\begin{array}{l}0.368 \\
0.402 \\
0.442 \\
0.447 \\
0.470 \\
0.493 \\
0.529 \\
0.563 \\
0.570\end{array}$ & $\begin{array}{l}10.0 \\
11.0 \\
12.4 \\
14.0 \\
16.0 \\
17.0 \\
18.0 \\
19.0 \\
20.2\end{array}$ & $\begin{array}{l}0.408 \\
0.456 \\
0.478 \\
0.496 \\
0.509 \\
0.535 \\
0.594 \\
0.642 \\
0.631\end{array}$ & $\begin{array}{l}10.0 \\
11.0 \\
12.5 \\
14.0 \\
16.0 \\
17.0 \\
18.0 \\
19.0 \\
20.2\end{array}$ \\
\hline \multicolumn{6}{|c|}{ Engine speed $=2400 \mathrm{rev} / \mathrm{min}$} \\
\hline $\begin{array}{l}8.63 \\
13.68 \\
18.73 \\
24.79 \\
29.83 \\
35.89 \\
41.44 \\
46.80 \\
53.56\end{array}$ & $\begin{array}{l}0.463 \\
0.509 \\
0.592 \\
0.680 \\
0.735 \\
0.829 \\
0.887 \\
1.013 \\
1.132\end{array}$ & $\begin{array}{l}0.333 \\
0.299 \\
0.278 \\
0.279 \\
0.303 \\
0.312 \\
0.328 \\
0.344\end{array}$ & $\begin{array}{r}8.0 \\
12.0 \\
14.0 \\
15.2 \\
16.0 \\
17.0 \\
17.5 \\
18.0\end{array}$ & $\begin{array}{l}0.349 \\
0.319 \\
0.298 \\
0.295 \\
0.324 \\
0.366 \\
0.383 \\
0.456\end{array}$ & $\begin{array}{r}8.0 \\
12.0 \\
14.0 \\
15.2 \\
16.0 \\
17.0 \\
17.5 \\
18.0\end{array}$ \\
\hline
\end{tabular}

deliver the same power output. As a mixture of gas and air is inducted during the induction stroke, the compression work of the gas-fuelled engine would be expected to be higher than when running on pure diesel fuel. It is also postulated that combustion continues well into the expansion stroke and that the internal energy of the fuel is not efficiently converted into useful work but appears in the form of high combustion exhaust temperature, which is indeed observed. Engine operation is smoother with the advanced injection timing unit.

\subsection{Ignition delay}

Ignition delays for dual-fuel operations are compared with the baseline test results on pure diesel fuel as shown in figures $3 a$ and $b$. The ignition delay in a diesel engine is defined as the time interval between the start of fuel injection and the start of combustion. Diesel fuel operation produces the shortest delay periods at both speeds tested. Standard dual timing at $3000 \mathrm{rev} / \mathrm{min}$, shows longer delay periods at high loads than the advanced injection timing operation. There is a very significant difference between the ignition delays of diesel fuel and dual-fuel operations at $2400 \mathrm{rev} / \mathrm{min}$. Standard dual timing also shows the longest delay period. It is seen that at high loads and combustion temperatures the ignition delay is reduced and combustion is dominated by the system temperature. At low loads with longer delay periods, greater proportion of pilot fuel takes part in premixed combustion, thus increasing the tendency of diesel to knock. Spray characteristics of pilot fuel in relation to the size, shape and velocity are bound to change in the prevailing conditions of a mixture of gas and air. Fuel penetration and spray cone angle depend on the density of the air in the 

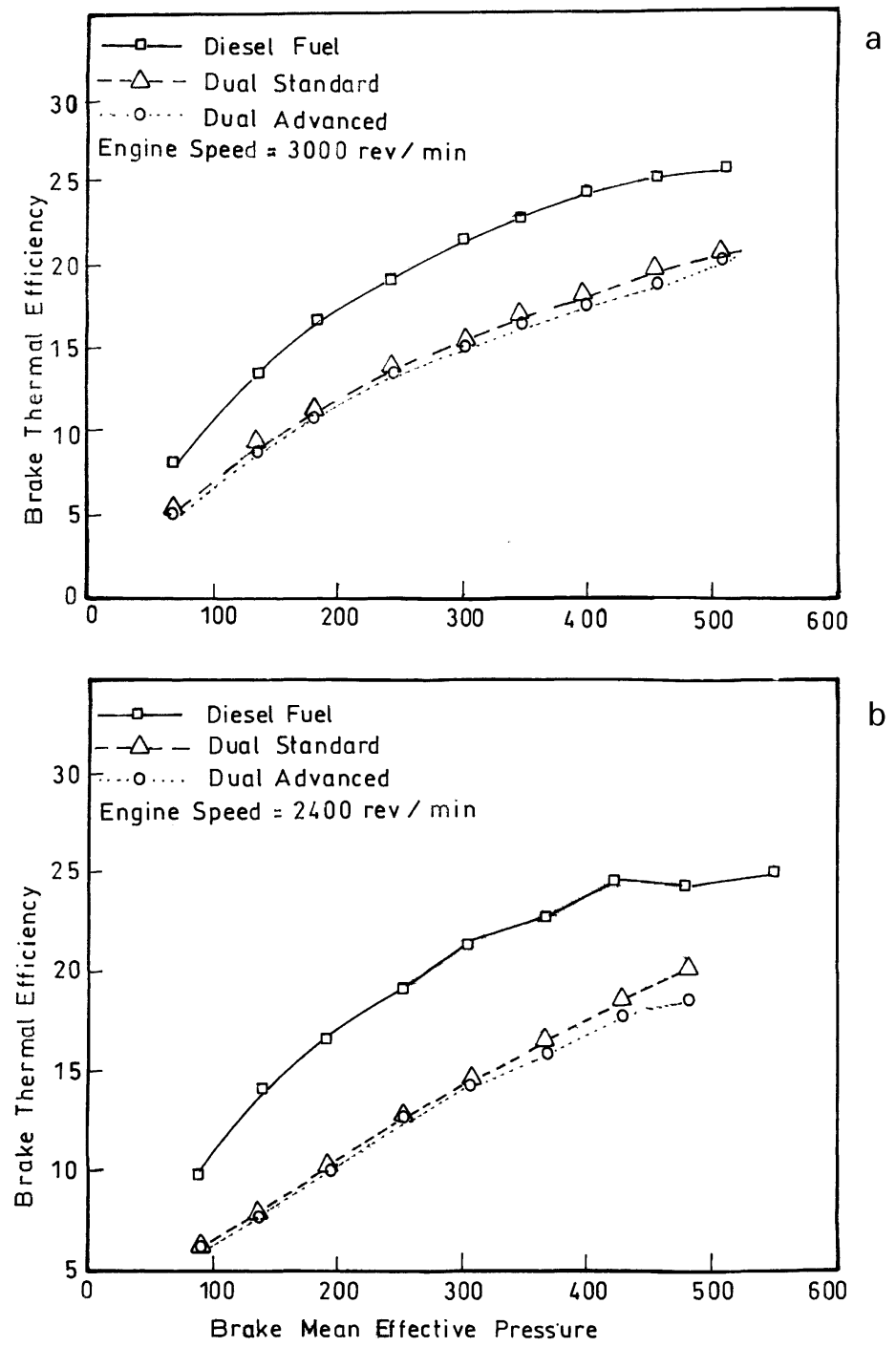

Figure 2. Injection advanced effect on gas combustion - BMEP $\left(\mathrm{kN} / \mathrm{m}^{2}\right)$ vs. BTE $(\%)$.

cylinder. Very poor atomization results in a relatively long delay period, due perhaps to the slow development of very fine droplets. Self-ignition temperature of natural gas is higher than that of diesel fuel. It was thought that greater amount of heat is needed to preheat the mixture when chemical reactions take place. This would have an adverse effect by reducing the temperature and pressure of the charge and consequent increase in the delay period.

\subsection{Exhaust temperatures}

There is significant difference between exhaust temperatures in dual-fuel operation and when running on pure diesel fuel as shown in figures $4 a$ and $b$. Dual-fuel operation with advanced timing shows the highest exhaust temperatures at $3000 \mathrm{rev} / \mathrm{min}$. The dual with 

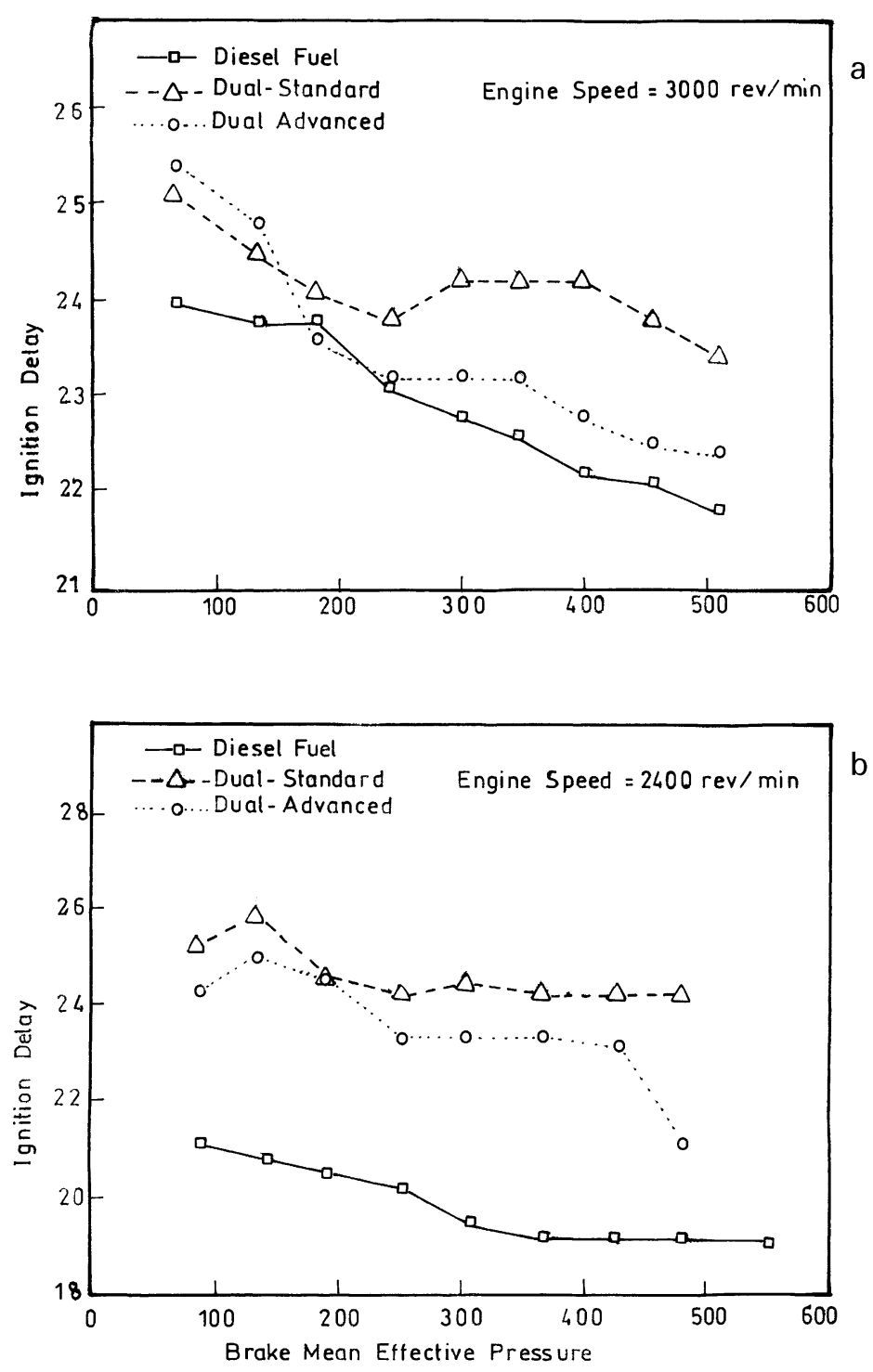

Figure 3. Injection advanced effect on gas combustion - BMEP $\left(\mathrm{kN} / \mathrm{m}^{2}\right)$ vs. ignition delay (deg.).

the standard timing also shows a marginal increase over the operation on pure diesel fuel. The standard timing dual unit produced the highest cylinder wall temperatures while the advanced system showed the lowest values at this speed. At $2400 \mathrm{rev} / \mathrm{min}$ speed, there is no marked difference in the exhaust temperatures. However, the diesel fuel operation produces the lowest cylinder wall temperatures, whereas the standard unit offers the highest values. The best fuel economy is realised when running on pure diesel fuel. These results explain why the thermal efficiency of the gas engine is less than when the operation is on pure diesel fuel. 

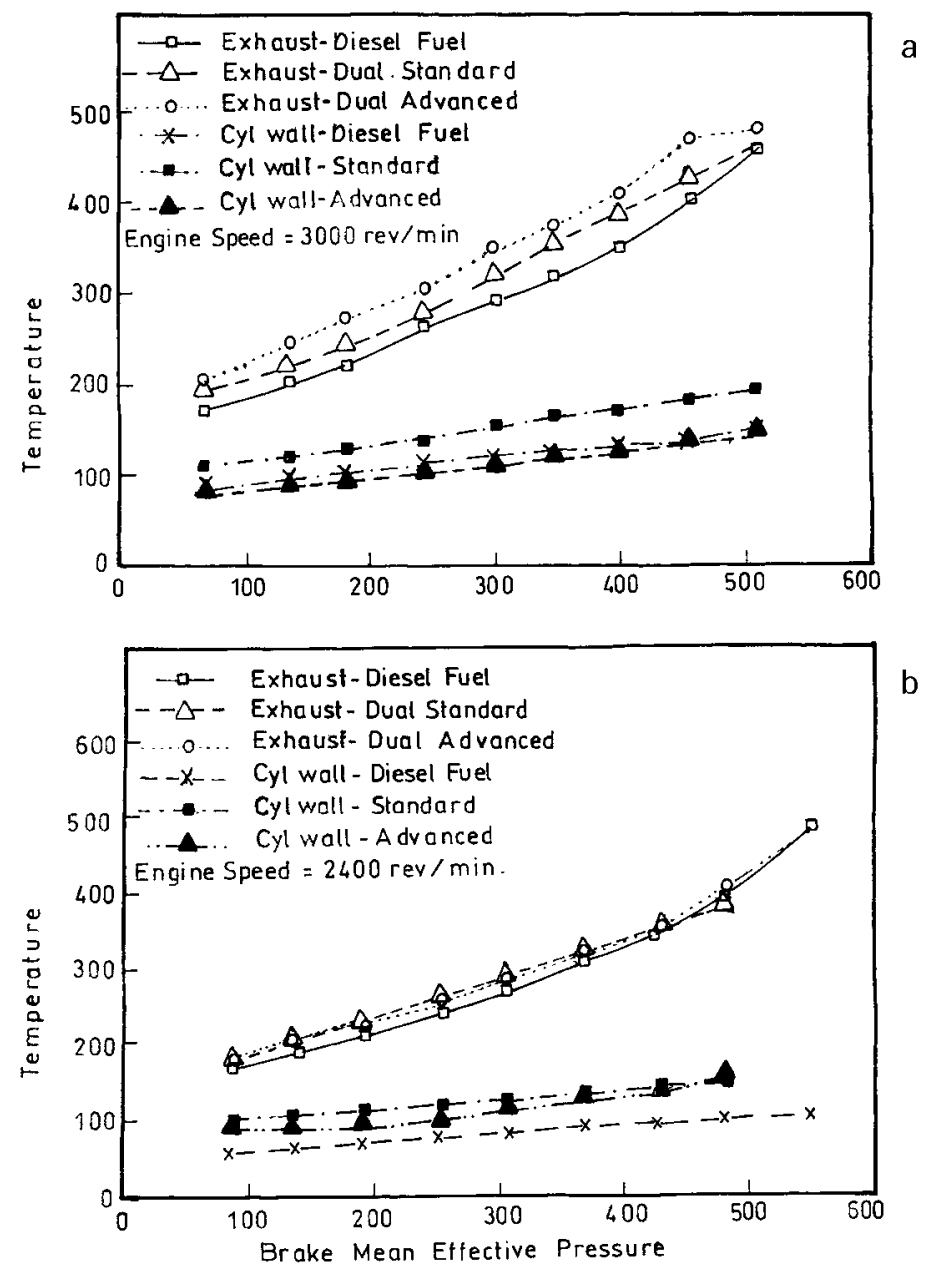

Figure 4. Injection advanced effect on gas combustion - BMEP $\left(\mathrm{kN} / \mathrm{m}^{2}\right)$ vs. temperature $\left({ }^{\circ} \mathrm{C}\right)$.

\subsection{Hydrocarbon (HC) emissions}

Figures 5a and $\mathrm{b}$ show plots of hydrocarbon (HC) emissions in dual-fuel and diesel fuel operations at both speeds of investigation. The results indicate that the HC emissions of the gas-fuelled engine are higher than that in pure diesel fuel operation. Diesel fuel operation gives the lowest HC emissions at both speeds. Dual standard timing shows higher concentration of $\mathrm{HC}$ in the exhaust at low load levels over the advanced injection unit. However, this system shows decreased HC emission levels at high load level operation. There is no marked difference in HC emissions between the standard and advanced injection systems at $2400 \mathrm{rev} / \mathrm{min}$. These results indicate that greater proportion of gas escapes primary combustion due to the slower burning rate. Hydrocarbon emissions increase due to several factors, including quenched, lean combustion, wall wetting, cold starting and poor mixture preparation. For both test conditions, the HC levels are relatively high in dual-fuel operations and stay reasonably high throughout the load range. The wider valve overlap of 

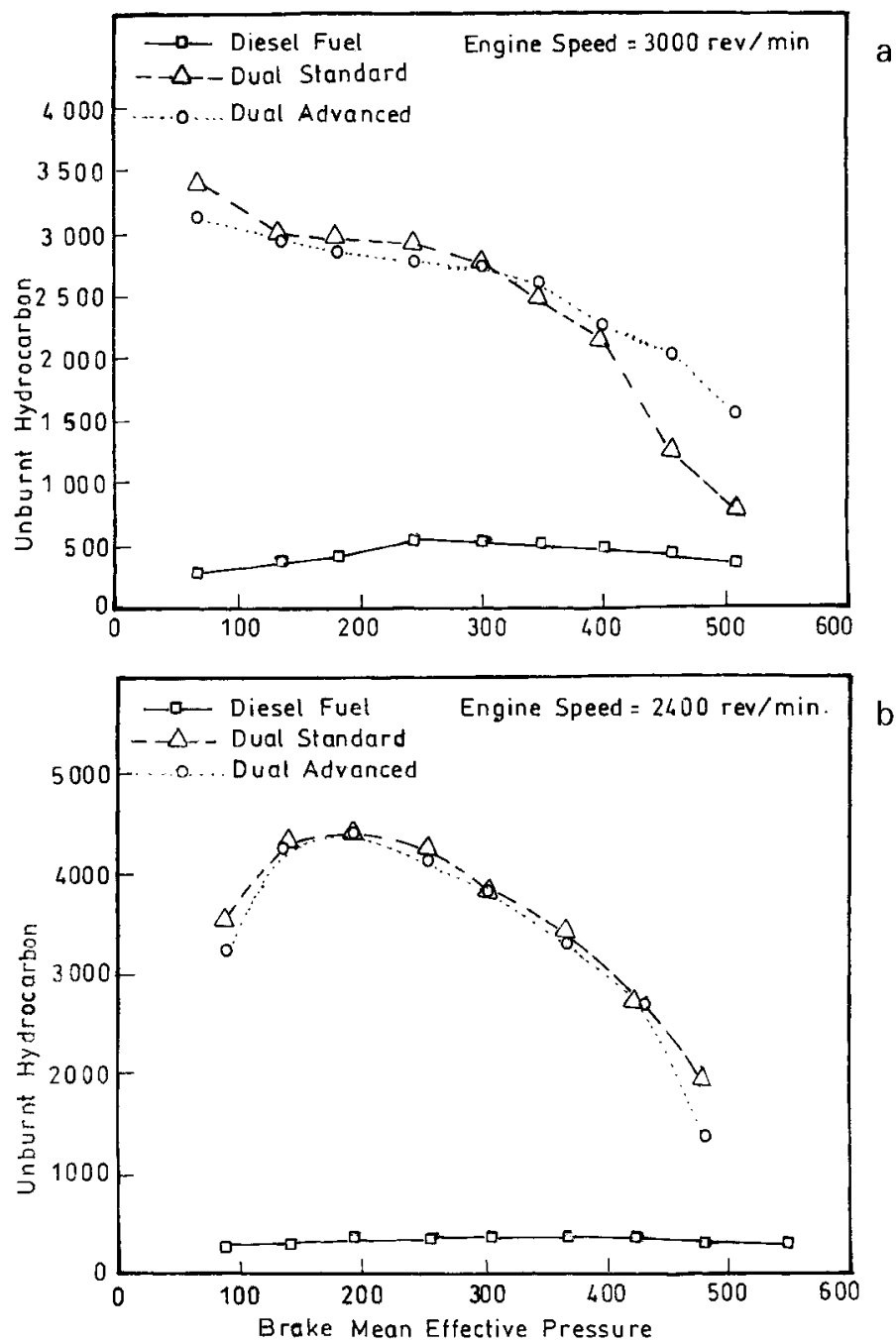

Figure 5. Injection advanced effect on gas combustion - BMEP $\left(\mathrm{kN} / \mathrm{m}^{2}\right)$ vs. unburnt hydrocarbons (ppm).

diesel engine is likely to result in greater proportion of the fresh charge leaving with the products of combustion. Table 2 shows the emission characteristics of the advanced injection timing system and that $\mathrm{CO}_{2}$ emissions increase with increase in engine load. Similar trends are noted with other test systems also. $\mathrm{CO}$ emissions appear to be influenced by engine load and mixture strength.

\section{Conclusions}

The test results show that alternative fuels exhibit delay characteristics which appear to be influenced by load, speed and the system temperature. The test results with the advanced injection timing show that each alternative fuel requires injection advance appropriate to its delay period. It is found that advanced timing tends to cause a slight increase in fuel 
Table 2. Effect of injection advance on natural gas performance. Pilot fuel $=$ diesel fuel.

\begin{tabular}{llllllr}
\hline $\begin{array}{l}\text { Load } \\
(\mathrm{N})\end{array}$ & $\begin{array}{l}\mathrm{uHC} * \\
(\mathrm{ppm})\end{array}$ & $\% \mathrm{CO}$ & $\% \mathrm{CO}_{2}$ & $\% \mathrm{O}_{2}$ & $\begin{array}{c}\text { Exhaust } \\
\text { temp. }(\mathrm{C})\end{array}$ & $\begin{array}{r}\text { Cyl. wall } \\
\text { temp. (C) }\end{array}$ \\
\hline $\begin{array}{l}\text { Engine speed }=3000 \mathrm{rev} / \mathrm{min} \\
6.61\end{array}$ & & & & & \\
13.18 & $3,126.7$ & 0.125 & 1.66 & 16.15 & 202.5 & 76.0 \\
17.72 & $2,935.0$ & 0.135 & 1.91 & 15.00 & 243.0 & 84.0 \\
23.78 & $2,850.0$ & 0.135 & 2.07 & 14.20 & 268.0 & 91.0 \\
29.33 & $2,775.0$ & 0.135 & 2.28 & 13.20 & 301.0 & 99.5 \\
33.87 & $2,727.5$ & 0.135 & 2.43 & 12.20 & 345.5 & 107.5 \\
38.92 & $2,592.5$ & 0.135 & 2.69 & 11.25 & 368.5 & 114.0 \\
44.47 & $2,255.0$ & 1.135 & 3.15 & 9.90 & 402.5 & 120.5 \\
49.52 & $2,018.5$ & 0.145 & 3.49 & 8.55 & 464.0 & 133.0 \\
Engine speed & $1,545.5$ & 0.155 & 3.70 & 7.25 & 474.5 & 144.5 \\
8.63 & $2400 \mathrm{rev} / \mathrm{min}$ & & & & & \\
13.18 & $3,227.5$ & 0.200 & 2.66 & 15.55 & 177.5 & 87.5 \\
18.73 & $4,239.2$ & 0.240 & 2.63 & 15.15 & 207.0 & 89.0 \\
24.79 & $4,389.3$ & 0.255 & 2.87 & 14.45 & 225.0 & 90.0 \\
29.83 & $4,097.9$ & 0.220 & 3.42 & 13.20 & 252.0 & 99.5 \\
35.89 & $3,796.7$ & 0.185 & 3.93 & 12.00 & 285.5 & 113.0 \\
41.95 & $3,287.9$ & 0.130 & 4.49 & 10.55 & 314.0 & 126.0 \\
47.00 & $2,663.6$ & 0.135 & 5.16 & 8.90 & 352.0 & 136.0 \\
\hline
\end{tabular}

* unburnt hydrocarbons

consumption. The dual-fuel engine offered higher BSFC. The BTE results with the advanced and standard timing of dual-fuel operation are similar and lower than the baseline test results at both speeds. The power output of gas-fuelled engine is low compared to test results on diesel fuel. The engine runs smoothly at light load conditions in dual-fuel with advanced timing of $3.5^{\circ}$ compared to the standard timing. A further $1.5^{\circ}$ advance tends to produce very erratic behaviour of the engine. The test results indicate that dual-fuel combustion produces larger percentage of $\mathrm{HC}$ emissions than when running on pure diesel fuel. There seems to be a significant reduction in $\mathrm{CO}$ and $\mathrm{CO}_{2}$ emissions when running with the advanced unit. At high loads, the combustion temperature is the dominant factor with a resultant reduction in delay period. Injection advance is therefore not recommended at high load conditions.

\section{References}

Boam D J, Finlay I C, Biddulp T W 1992 Sources of unburnt hydrocarbon emissions from spark ignition engines during cold start and warm-up. Proc. Inst. Mech. Eng. (London) 448: 57-72

Heywood J B 1988 Internal combustion engine fundamental (New York: McGraw Hill)

Karim G A, Ali A I 1975 Combustion, knock and emission characteristics of a natural gas fuelled spark ignition engine with particular reference to low intake temperatures. Proc. Inst. Mech. Eng. (London) 189: 139-147

Needham J R, Doyle D M 1985 The combustion and ignition quality of alternative fuels in light duty diesels. Proc. SAE 852101: 1-21

Nwafor O M I, Rice G 1994 Combustion characteristics and performance of natural gas in a high speed indirect injection diesel engine. Proc. World Renewable Energy Congress (ed.) A A M Sayigh, vol. 2, p. 841 